\title{
KESENIAN SISINGAAN SUBANG SUATU TINJAUAN HISTORIS
}

\section{A SISINGAAN (LION) DANCE ART SUBANG: A HISTORICAL REVIEW}

\author{
Anggi Agustian Junaedi, Nina Herlina Lubis, Kunto Sofianto \\ Jurusan Ilmu Sejarah UNPAD, Jalan Raya Bandung Sumedang Km. 21 Jatinangor \\ e-mail: anggiagustian81@gmail.com
}

\begin{abstract}
Abstrak
Kesenian sisingaan merupakan kesenian yang berasal dari daerah di sebelah utara Provinsi Jawa Barat bernama Kabupaten Subang. Sampai saat ini, kesenian sisingaan dipersepsikan oleh banyak orang sebagai bagian dari perjuangan rakyat yang dalam hal ini perlawanan terhadap tuan tanah atau penjajah. Namun, pendapat ini perlu ditinjau ulang mengingat beberapa pakar kesenian seperti Edih dan Armin Asdi yang mengatakan bahwa pada awalnya kesenian ini berfungsi sebagai alat untuk mengarak anak-anak yang akan dikhitan. Maka, untuk menjabarkan persoalan tersebut peneliti menggunakan metode sejarah yang terdiri dari heuristik, kritik, interpretasi dan historiografi. Berdasarkan penelitian yang dilakukan, kesenian sisingaan tidak lahir sebagai aksi perlawanan karena sebelum aksi tersebut terjadi, kesenian ini telah ada dan beberapa kali digelar pada acara khitanan. Setidak-tidaknya ada dua indikator yang dapat dikemukakan untuk menjelaskan latar belakang terbentuknya sisingaan. Pertama, ia merupakan bagian integral dari proses islamisasi di Subang. Kedua, sebagai bentuk penghormatan kepada P.W. Hofland karena telah berjasa membangun Subang beserta penduduknya.
\end{abstract}

Kata kunci: kesenian sisingaan, historis, Subang.

\section{Abstract}

Sisingaan (lion dance) is an art that comes from the area in the north of West Java Province; Subang Regency. Until now, the Sisingaan has been defined as a part of people's struggle against the landlords or the colonialists. However, this opinion needs to be reviewed considering some art experts such as Edih and Armin Asdi who said that firstly this art is served as a tool to parade children who will be circumcised. Therefore, to describe the problem, researchers use historical methods consisting of heuristics, criticism, interpretation and historiography. Based on research conducted, Sisingaan was not born as an action of resistance because before the action occured, this art has existed and several times held at circumcision event. There are at least two indicators that can be put forward to explain the background of the formation of Sisingaan. First, it is an integral part of the Islamization process in Subang. Second, as a form of respect to P.W. Hofland for his contribution in building Subang and its residents.

Keywords: Sisingaan, Historic, Subang.

\section{A. PENDAHULUAN}

Indonesia merupakan tempat hidup dan berkembangnya berbagai macam kesenian yang tersebar dari Sabang sampai Merauke. Tiap-tiap daerah memiliki keseniannya masing-masing yang tentunya berbeda-beda antara satu daerah dengan daerah lainnya. Umpamanya, Aceh dengan tari saman-nya, Ponorogo dengan reognya, Bali dengan tari kecak dan tari legong-nya, Cirebon dengan sintren-nya dan masih banyak lagi kesenian lainnya yang khas dari berbagai daerah di Indonesia. 
Daerah lainnya yang patut dicatat adalah daerah yang terletak di sebelah utara Provinsi Jawa Barat bernama Subang. Subang adalah salah satu daerah yang memiliki banyak kesenian. Umpamanya, kesenian gembyung, doger kontrak, jaipongan dan sisingaan. Sebenarnya masih banyak kesenian lainnya yang belum disebutkan dari daerah ini. Namun demikian, kesenian yang paling khas dan bahkan menjadi simbol dari daerah ini adalah kesenian sisingaan. Hal ini dibuktikan dengan ditempatkannya patung manusia yang sedang bermain sisingaan di pusat Kota Subang.

Sebagai kesenian yang paling khas, sisingaan terus mengalami perkembangan yang cukup signifikan. Banyaknya grup sisingaan yang ada di Kabupaten Subang membuktikan hal itu. Hal ini tentu tidak lepas dari besarnya antusias masyarakat terhadap sisingaan yang kemudian menjadi sumber motivasi bagi mereka untuk tetap melestarikan kesenian tersebut melalui grup-grup yang mereka dirikan. Besarnya antusias itu terefleksikan pada seringnya Kesenian sisingaan digunakan pada berbagai acara seperti acara pernikahan, khitanan dan acara lainnya baik sebagai pembuka maupun sebagai penutup acara.

Setiap kesenian di berbagai daerah tentu memiliki sejarahnya masing-masing, kapan munculnya dan apa yang melatarbelakanginya. Kesenian sisingaan juga memiliki sejarah yang sangat panjang. Akan tetapi, sampai hari ini belum ditemukan angka yang tepat untuk menunjukkan sejak kapan sebenarnya sisingaan muncul.

Sampai hari ini, masyarakat umum mempercayai bahwa sisingaan lahir sejak Subang menjadi tanah swasta. Selama menjadi tanah swasta, rakyat Subang mengalami banyak penderitaan karena tuan tanah mewajibkan mereka untuk bekerja menjadi buruh perkebunan dengan upah yang sangat kecil. Bahkan tidak sedikit dari mereka yang tidak mendapatkan upah. Akibatnya, banyak rakyat Subang yang pada akhirnya melawan tuan tanah dan salah satunya adalah melalui kesenian bernama sisingaan ${ }^{1}$. Dengan demikian dapat dikatakan bahwa sisingaan lahir sebagai bentuk perlawanan rakyat Subang terhadap tuan tanah atau penjajah. Tokoh yang mendukung dengan asumsi tersebut di antaranya adalah Ukat Mulyana yang dikenal sebagai "Kang Robot" sekaligus sebagai seniman sisingaan Subang (Dewi, dkk., 2015: 5).

Namun demikian, berbicara sisingaan secara historis tentu harus berbicara data dan fakta. Sampai hari ini belum ditemukan data yang akurat untuk memperkuat asumsi tadi. Dengan demikian, hal itu masih memungkinkan untuk diperdebatkan kembali.

Sejarah munculnya sisingaan di Subang sangat menarik untuk dikaji karena sampai hari ini terkait dengan kapan kesenian ini lahir, siapa yang menciptakannya, dan di mana tempat lahirnya masih menjadi misteri meskipun beberapa orang telah mencoba meneliti hal itu baik yang dilakukan oleh seniman sisingaan maupun akademisi dengan hasil yang berbeda-beda.

Selain itu, terdapat pendapat yang agaknya perlu ditinjau ulang berkenaan dengan gerakan perlawanan yang kerap kali dikaitkan dengan lahirnya sisingaan. Padahal, alasan-alasan berikut kiranya dapat dipertimbangkan untuk mempertimbangkan kembali asumsi tersebut. Pertama, gerakan perlawanan di Subang menurut Iim Imadudin baru terjadi pada 1913 (Imadudin, 2013: 165-166). Padahal, sisingaan telah ada sebelum tahun tersebut yang dibuktikan dengan pengakuan seorang lurah di Cigadung yang pernah diarak menggunakan sisingaan pada 1910 (Alamsyah, 2015: 4-5). Kedua, hampir semua pakar sisingaan sepakat bahwa pada awalnya kesenian ini difungsikan untuk mengarak anak-anak

\footnotetext{
${ }^{1}$ Dalam hal ini, kesenian sisingaan digunakan untuk menyulut semangat nasionalisme yang berarti membebaskan diri dari belenggu tuan tanah atau penjajah (Saini, 2001: 1).
} 
yang akan dikhitan. Dengan demikian, betulkah sisingaan lahir sebagai bentuk perlawanan?

Terkait dengan hal tersebut maka muncul beberapa persoalan seperti: Bagaimana sejarah munculnya sisingaan di Subang? Benarkah kesenian sisingaan muncul sebagai sikap perlawanan rakyat Subang terhadap tuan tanah atau penjajah?

Penulisan artikel ini tentu bukan tanpa tujuan. Tulisan ini diharapkan dapat memberikan informasi dan pengetahuan kepada semua orang terutama untuk mereka yang berkepentingan dengan sejarah sisingaan. Adanya bukti-bukti baru yang relevan mengantarkan penulis untuk mengupas kembali sejarah sisingaan yang selama ini masih menjadi misteri.

Pada penelitian terdahulu, Dewi (2013) mengungkapkan tentang sejarah munculnya sisingaan yang disebutnya berbarengan dengan ditetapkannya Subang menjadi tanah swasta pada 1812; Puspitasary (2013) menguraikan tentang masuknya pengaruh komersial pada kesenian sisingaan yang sekaligus menjadi tanda telah terjadinya pergeseran makna dalam kesenian tersebut; Mulyadi (2007) mendeskripsikan mengenai sejarah singkat sisingaan, perkembangan fungsi sisingaan dari masa ke masa dan menolak asumsi mengenai sisingaan yang lahir sebagai bentuk perlawanan; Alamsyah (2015) memaparkan mengenai sejarah sisingaan dengan menghadirkan asumsi beberapa peneliti sisingaan seperti Edih, Armin Asdi, dan Nanu Munajar. Cakupan waktu yang dikaji dalam penelitian ini cukup panjang yaitu dari abad ke-15 sampai dengan abad ke-20. Adapun wilayah penelitian yang dikaji adalah Kabupaten Subang.

\section{B. METOdE PENELITIAN}

Penelitian ini menggunakan metode sejarah yang terdiri atas heuristik, kritik, interpretasi, dan historiogafi. Tahap pertama dari metode sejarah adalah heuristik. Pada tahapan ini penulis mencari dan menghimpun sumber, informasi, jejak masa lampau yang berkaitan dengan objek yang diteliti (Herlina, 2008: 7-15).

Setelah sumber terhimpun, maka dilakukan tahapan kedua, yaitu kritik. Kritik terdiri atas kritik eksternal dan kritik internal. Kritik eksternal dilakukan dengan meneliti keaslian sumber dan kritik internal dengan meneliti kredibilitas sumber (Kuntowijoyo, 2013: 77-78).

Namun demikian, sumber yang telah dikritik belum dianggap sebagai fakta sejarah. Untuk itu, perlu dilakukan koroborasi suatu sumber sejarah dengan sumber lain yang bersifat merdeka sehingga menghasilkan fakta yang mendekati kepastian. Jika koroborasi tidak bisa dilakukan, maka berlaku prinsip argumentum ex silentio, sumber yang berisi data dianggap sebagai fakta (Gottschalk, 2008: 130; Herlina, 2008: 34$35)$.

Tahapan ketiga disebut dengan interpretasi. Tahapan ini terdiri atas analisis (menguraikan) dan sintesis (menyatukan). Interpretasi disebut sebagai biang subjektifitas. Untuk itu, pada tahapan ini, penulis harus mengambil jarak dengan sumber agar tidak terlalu dekat dan menimbulkan bias. Dikenal beberapa jenis interpretasi, yaitu interpretasi verbal, teknis, logis, psikologis, dan faktual. Tahapan akhir dari metode sejarah disebut dengan historiografi (Herlina, 2008: 36$60)$.

Untuk penjelasan yang bersifat analitis, penulis menggunakan konsep seni dan politik. Eratnya kaitan antara keduanya disebut Saini dengan political theatre karena di dalam seni terdapat berbagai kepentingan yang menyertainya (Saini, 2001: 1). Oleh karena itu, memandang seni sebagai kepentingan merupakan cara berfikir kritis dalam menganalisis sejarah munculnya kesenian sisingaan di Subang.

Sebagaimana dikatakan Albert Camus bahwa seni diciptakan oleh masyarakat. Ia adalah wujud dari kreativitas manusia baik secara individu maupun kelompok. Melalui seni seseorang dapat berekspresi, mengeluarkan jati 
dirinya. Lebih jauh, seni dapat digunakan untuk kepentigan tertentu oleh kalangan tertentu pula (Camus, dkk., 1998: xxvi). Dalam hal ini, sisingaan digunakan oleh masyarakat Subang untuk kepentingan politik.

Pada dasarnya semua orang dapat menciptakan seni. Namun tidak semuanya memiliki kemampuan untuk mengembangkan seninya lebih jauh lagi hingga dikenal oleh masyarakat luas. Artinya hanya orang-orang tertentu saja yang dapat melakukannya terutama pada seni pramodern. Sebagaimana dikatakan Ahmad Norma bahwa seni pramodern hanya ada di kelompok-kelompok elite tertentu. Ia jauh dari kehidupan rakyat jelata yang secara strata sosial berada di bawahnya. Ia juga dapat menjadi alat yang dikendalikan kekuasaan (Camus, dkk., 1998: xxi). Dengan perkataan lain, seni diciptakan oleh para penguasa untuk mengendalikan berbagai hal sesuai dengan kepentingan.

Namun demikian, Leon Trotsky berpandangan lain terkait dengan hal itu. Ia berpandangan bahwa sebenarnya seni merupakan ekspresi dari masyarakat yang tertindas oleh para penguasa (Camus, dkk., 1998: 27). Artinya seni diciptakan bukan oleh para penguasa melainkan oleh rakyat yang berada di bawahnya sebagai akibat telah dirampasnya hak-hak mereka. Oleh karena itu, analisis yang dilakukan untuk mengungkap siapa yang melahirkan seni berupa sisingaan tidak hanya terfokus kepada kalangan tertentu saja melainkan seluruh lapisan masyarakat baik rakyat jelata maupun elite sehingga diharapkan mampu memberikan hasil yang maksimal.

\section{HASIL DAN BAHASAN \\ 1. Asal-usul Kesenian Sisingaan}

Kesenian sisingaan ${ }^{2}$ merupakan kesenian yang berasal dari Subang. Ia

2 Sisingaan memiliki kata dasar singa. Ia mendapatkan awalan si- dan akhiran-an. Dalam kepercayaan masyarakat Sunda, apabila sebuah kata mendapatkan awalan dengan pengulangan morfem awal pada kata dasar merupakan seni pertunjukan dalam bentuk arak-arakkan yang biasanya dilakukan dalam hajat sunatan ${ }^{3}$.

Terkait dengan asal-usul kesenian sisingaan, ada beberapa pendapat yang telah dikemukakan oleh para pakar sisingaan baik yang didasarkan pada cerita yang berkembang di masyarakat maupun pada bukti-bukti yang telah mereka temukan. Namun, hampir semua pakar meyakini bahwa kemunculan sisingaan memiliki kaitan yang erat dengan situasi sosial politik Subang pada masa penjajahan.

Pendapat pertama dikemukakan oleh Yuliadi Soekardi yang mendasarkan pada cerita yang berkembang di masyarakat. Ia mengatakan bahwa Sisingaan diciptakan oleh seseorang yang berasal dari Desa Ciherang ${ }^{4}$. Ia menggambarkan tokoh tersebut dalam bukunya sebagai seorang rakyat biasa yang bekerja sebagai buruh perkebunan di Desa Ciherang. Pemikirannya melampaui orangorang pada umumnya. Ia selalu memikirkan nasib dirinya dan rakyat Subang yang berada dalam tekanan dan siksaan para penjajah. Kondisi demikian membuat dirinya semakin benci terhadap penjajah dan ingin melakukan perlawanan terhadap mereka. Namun demikian, ia sadar bahwa tidak mungkin melakukan perlawanan hanya seorang diri dan tanpa adanya persatuan dari rakyat Subang untuk melakukan yang sama. Untuk itu, ia mencoba mencari cara terbaik untuk melakukan perlawanan. Jalan keluar dari

tersebut dan kemudian diakhiri dengan akhiran -an maka kata tersebut memiliki arti menyerupai seperti si-singa-an, ku-kuda-an, mo-mobil-an, dan lain sebagainya.

${ }^{3}$ Sunatan adalah ritual dalam Islam yang diperuntukan bagi anak laki-laki dengan memotong bagian tertentu dari alat reproduksinya.

${ }^{4}$ Di dalam bukunya, ia memberi nama tokoh pencipta sisingaan dengan nama fiktif bernama Tarya (Soekardi, 2006: 1). 
persoalan tersebut adalah melalui kesenian bernama sisingaan (Soekardi, 2006: 3-13).

Bentuk perlawanan melalui simbol sisingaan terhadap penjajah dapat ditelusuri melalui nilai-nilai filosofis yang terdapat pada sisingaan. Adapun nilai-nilai filosofis itu adalah sebagai berikut:

- Boneka singa yang diusung merupakan lambang kebesaran penjajah (Inggris dan Belanda).

- Empat orang pengusung singa adalah rakyat Subang yang sedang ditindas penjajah.

- Sementara itu anak kecil yang duduk di atas singa adalah generasi penerus Subang yang akan melawan tirani dan mengusirnya dari tanah Subang (Mulyadi, 2003: 7).

Melalui nilai filosofis tersebut pencipta kesenian (yang masih belum diketahui siapa) menginginkan adanya persatuan dari rakyat Subang ketika sisingaan digelar. Ia berharap rakyat Subang dapat menangkap nilai-nilai tersebut agar bersatu melawan penjajah. Meskipun demikian, tidak dapat diyakini apakah saat itu masyarakat Indonesia khususnya masyarakat Subang sudah mampu membuat nilai-nilai filosofis yang cukup tinggi seperti yang terdapat pada sisingaan. Apalagi berkaitan dengan proses penyampaian dan penerimaan nilai-nilai tersebut yang sifatnya tersembunyi mengingat pemikiran masyarakat saat itu belum seperti hari ini yang mampu melihat lebih jauh makna-makna yang terdapat dalam berbagai simbol.

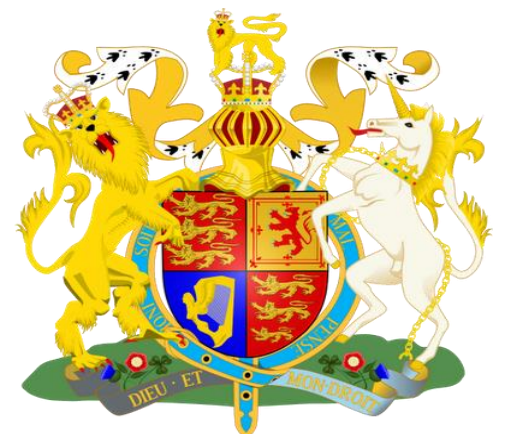

Gambar 1. Lambang Kerajaan Inggris Sumber: http://ispu.ru/files/The_UK.pdf.
Sejalan dengan pendapat pertama, Edih sebagai pakar sisingaan menyatakan hal yang sama terkait dengan daerah asal pencipta sisingaan yaitu Desa Ciherang. Namun, Edih memiliki pandangan lain terkait dengan siapa yang telah menciptakan kesenian itu. Ia mengatakan bahwa orang yang menciptakan sisingaan adalah seorang elite pribumi bergelar Demang di Desa Ciherang pada 1857 yaitu Demang Mas Tanudireja. Pendapatnya ini didasarkan atas penelitiannya selama empat tahun (1981-1985) mengenai sejarah lahirnya sisingaan di Subang dengan menggunakan metode wawancara. Dari penelitiannya tersebut ia menemukan beberapa fakta sebagai berikut: pertama, pada 1910, seorang lurah di Cigadung bernama Lurah Sayung mengaku pernah diarak menggunakan sisingaan sebagai ucapan rasa syukur dan luapan kegembiraan pendukungnya ketika dirinya terpilih sebagai lurah di sana. Fakta kedua, pada 1920, Patih Oman juga mengaku bahwa ia pernah diarak menggunakan sisingaan saat dikhitan. Terakhir, pada 1927, Suparno mengalami hal yang sama dengan Patih Oman yaitu pernah diarak menggunakan sisingaan saat dirinya akan dikhitan (Alamsyah, 2015: 4-5).

Pendapat ketiga datang dari pakar sisingaan lainnya bernama Armin Asdi. Dalam mengkaji asal-usul kesenian sisingaan, ia mencoba melacaknya melalui penguasaan daerah Subang oleh para tuan atau pemilik tanah. Diketahui bahwa sejak Raffles menjadikan Subang sebagai tanah partikelir melalui penjualan sebagian tanah negara pada 1813, daerah ini telah mengalami tiga periode pergantian kekuasaan. Sejarah mencatat pada periode pertamanya daerah Subang dimiliki orang Inggris selama dua puluh tujuh tahun (1813-1840). Setelah berakhirnya masa kepemilikian orang Inggris, kepemilikan tanah Subang dilanjutkan oleh orang Belanda bernama P.W. Hofland. Kepemimpinannya di Subang sebagai tuan tanah terekam dalam sejarah selama tiga puluh dua tahun (1840-1872) setelah 
kematian membuatnya melepaskan status tuan tanah di Subang. Penguasaan tanah Subang kemudian dilanjutkan oleh anakanak Hofland sampai dengan 1911. Dari masa Hofland sampai dengan penerusnya dianggap sebagai satu periode karena dimiliki satu keluarga. Setelah dinasti keluarga Hofland berakhir pada 1911 akibat menurunnya pendapatan yang diterima oleh mereka. Periode terakhir penguasaan Subang kembali lagi kepada orang Inggris berbentuk perusahaan bernama The Anglo-Dutch Plantation of Java, Limited. Perusahaan ini menguasai daerah Subang selama empat puluh tiga tahun (1911-1954) (Asdi, dkk., 1980: 40).

Dari tiga periode tersebut, Armin Asdi meragukan jika sisingaan lahir pada periode pertama. Hal ini didasarkan pada beberapa pertimbangan sebagai berikut: pertama, pada periode ini, daerah Subang belum dikelola secara sungguh-sungguh. Kedua, jumlah penduduk di Subang pada periode ini dapat dikatakan masih sangat jarang. Melalui dua pertimbangan tersebut Armin Asdi sampai pada kesimpulan bahwa tidak mungkin sisingaan sebagai karya seni yang cukup besar lahir pada kondisi-kondisi demikian.

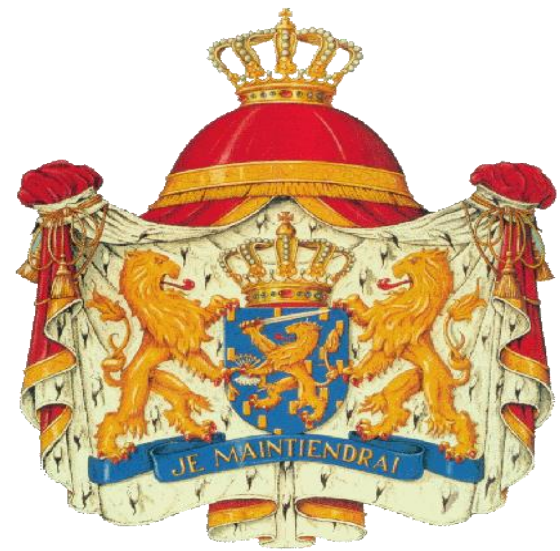

Gambar 2. Lambang Kerajaan Belanda Sumber:

http://symbolsnet.com/symbols/netherlandsnational-symbol.html.

Ia berasumsi bahwa kemungkinan terbesar lahirnya sisingaan adalah ketika Subang berada di bawah kepemimpinan Hofland. Pada saat itu, Hofland menjadikan tanah-tanah di Subang yang semula terbengkalai menjadi tanah-tanah yang produktif. Di saat yang bersamaan, hal tersebut berdampak kepada pembukaan perkebunan di beberapa daerah yang semula terbengkalai tersebut yang pada akhirnya membuat kebutuhan akan tenaga kerja semakin meningkat. Secara tidak langsung, pembukaan perkebunan yang dilakukan tuan tanah berdampak kepada peningkatan jumlah penduduk di Subang menjadi lebih banyak dari sebelumnya. Kondisi ini kemudian ditambah dengan meningkatnya produktifitas perkebunan yang menimbulkan hasil ekspor meningkat sehingga Hofland bukan saja menambah pundi-pundi kekayaannya tetapi juga meningkatkan kesejahteraan rakyat Subang. Dalam kondisi-kondisi yang demikian, mungkin sekali sisingaan lahir. Namun bukan sebagai perlawanan seperti yang telah dipersepsikan banyak orang hari ini melainkan bersifat pemujaan atau sanjungan kepada tuan tanah (Rachmawaty, 2013: 496).

Pendapat keempat berasal dari seniman sisingaan lainnya bernama Mas Nanu Munajar. Berbeda dengan beberapa pakar sisingaan sebelumnya, Nanu Munajar memiliki pandangan lain terkait dengan asal-usul kesenian sisingaan. Menurut Nanu Munajar, sejak zaman dahulu, yaitu sebelum masuknya agamaagama besar ke Subang, daerah ini telah memiliki tradisi yang erat kaitannya dengan pertanian yang terwujud dalam upacara ngaruwat bumi. Tradisi itu disebut dengan tradisi odong-odong yang dalam pelaksanaannya hampir mirip dengan kesenian sisingaan hari ini yaitu mengarak suatu benda yang dibentuk menyerupai binatang tertentu. Dalam perkembangan berikutnya, tradisi ini kemudian berkembang terus menerus hingga melahirkan seni pertunjukan dan helaran dalam bentuk baru termasuk sisingaan. Menurutnya, nama sisingaan sendiri baru lahir pasca dilakukannya seminar kesenian sisingaan oleh dinas setempat ketika Subang diminta Pemerintah Indonesia 
untuk menampilkan dan mendelegasikan kesenian daerahnya (Rachmawaty, 2013: 496-497).

Pendapat terakhir datang dari seorang akademisi yang mencoba merekonstruksi kembali sejarah sisingaan. Enden Irma Rachmawaty sejalan dengan pemikiran Nanu Munajar yang memandang bahwa sisingaan merupakan transformasi dari tradisi odong-odong. Selain itu, ia sampai pada kesimpulan bahwa meskipun waktu dan siapa yang menciptakan sisingaan serta terdapat banyak tokoh daerah di Subang yang mengklaim bahwa daerahnya merupakan pencipta sisingaan, hal itu tidak membuat sisingaan kehilangan identitasnya sebagai kesenian yang benar-benar berasal dari Subang.

Dari kelima pendapat di atas setidak-tidaknya dapat ditarik beberapa kesimpulan sebagai berikut: pertama, sebagian besar pakar tanpa Nanu Munajar dan Enden meyakini bahwa sisingaan lahir sejak masuknya sistem perkebunan ke Subang. Kedua, sebagian pakar meyakini bahwa sisingaan lahir sebagai bentuk perlawanan penduduk terhadap penjajah. Sebagian pakar lainnya meragukan asumsi tersebut karena terdapat beberapa fakta yang membantahnya. Ketiga, hampir seluruh pakar sisingaan tanpa Nanu Munajar dan Enden meyakini bahwa pada awalnya kesenian ini difungsikan untuk mengarak anak-anak yang hendak dikhitan.

\section{Subang sebagai Perkebunan Swasta}

Sebagaimana telah dijelaskan sebelumnya bahwa kesenian sisingaan selalu dikaitkan dengan gerakan pemberontakan atau perlawanan penduduk terhadap penjajah sebagai dampak masuknya perkebunan ke Subang. Dengan perkataan lain, sejarah sisingaan tidak dapat dilepaskan dari sejarah Subang itu sendiri, terutama ketika masuknya perkebunan yang membawa tuan tanah ke Subang yang pada gilirannya melahirkan berbagai perlawanan termasuk melalui
Sisingaan seperti yang telah dipersepsikan sampai hari ini. Untuk itu perlu dipaparkan mengenai masuknya perkebunan ke Subang hingga perkembangannya sampai melahirkan aksi perlawanan.

Berakhirnya kekuasaan VOC di Indonesia ditandai dengan berdirinya suatu pemerintahan yang dibentuk oleh Kerajaan Belanda bernama Pemerintah HindiaBelanda. Pada awal pembentukannya, Kerajaan Belanda mengirimkan H.W. Daendels untuk mengatur pemerintahan di Hindia-Belanda. Pada saat ia berkuasa di Indonesia, ia mengubah sistem yang sebelumnya dijalankan oleh VOC. Ia membentuk Prefektur yang dipimpin oleh seorang Perfek. Di satu sisi, Pemerintah Hindia-Belanda sedang berada dalam masa transisi. Di sisi lain, untuk menjalankan roda pemerintahan di sana membutuhkan banyak biaya. Akibatnya muncul wacana untuk menjual sebagian tanah jajahan. Pada masa Daendels, penjualan tersebut berhasil dijalankan dan sebagian tanah jajahan seperti Jasinga, Besuki, Panarukan dan Probolinggo resmi menjadi milik swasta (Kusma, 2007: 28).

Kondisi demikian berlanjut hingga penggantinya yaitu Sir Thomas Stamford Raffles berkuasa di Hindia-Belanda. Menurut Machmoed Effendhie, terkait dengan penjualan tanah yang dilakukan oleh Raffles sebenarnya dilatarbelakangi oleh dua hal: pertama, kondisi keuangan Pemerintah Hindia-Belanda sangat buruk, sementara biaya operasional pemerintahan sangat tinggi. Kedua, masuknya kepentingan para kapitalis Eropa ke Pemerintah Hindia-Belanda yang kemudian mendesak Raffles agar menjual sebagian tanah jajahan kepada mereka (Effendhie, 1998: 160).

Pada 1812, sebagai akibat dari kebijakan yang ditetapkan oleh Raffles tersebut, daerah Subang dipilih oleh Raffles sebagai daerah yang akan dijual kepada siapa saja yang menginginkannya 
dengan hak eigendom ${ }^{5}$. Penjualan tanah itu diiklankan dalam Java Government Gazette selama lima hari pada bulan November $(5,7,14,21$ dan 28 November 1812). Pada 1813 tanah itu terjual kepada dua orang. Pemilik tanah Subang berasal dari Inggris yaitu James Sharpnel dan Philip Skelton. Pada saat itu mereka memberi nama daerah tersebut dengan nama Pamanoekan en Tjiassemlanden ${ }^{6}$ atau disingkat $\mathrm{P}$ en $\mathrm{T}$ (Asdi, dkk., 1980: 32-35; Imadudin, 2013: 49). Dengan demikian, pada awal abad ke-19 daerah Subang secara resmi ditetapkan menjadi tanah swasta.

Kurang lengkapnya sumber pada periode awal Subang menjadi tanah swasta membuat para peneliti sulit untuk merekonstruksinya termasuk penulis. Beberapa buku yang telah mencoba merekonstruksi pun tidak banyak memberikan informasi kecuali mengenai para pemilik saham dan mengenai tanahtanah di Subang yang menjadi perkebunan dan sawah. Satu hal yang perlu dicatat bahwa saat itu (sekitar 1825-1835) beras yang dihasilkan dari daerah Pamanoekan (Pamanukan) telah dikenal sampai ke pasar Amsterdam yang menunjukkan adanya potensi alam yang dimiliki Subang sehingga daerah ini dapat dikembangkan lebih jauh lagi (Pemerintah Kabupaten Subang, tt: 4).

\footnotetext{
${ }^{5}$ Hak eigendom adalah hak perseorangan yang kuat (tidak termasuk milik Negeri) dan dijamin oleh Undang-undang (Tauhid, 2011: 40). Dalam batas-batas tertentu hak eigendom memiliki pengertian yang sama dengan tanah apanage di mana tanah tersebut dapat dieksploitasi yang kemudian menghasilkan pajak berupa uang, barang dan tenaga kerja. Dengan demikian, tenaga kerja di tanah tersebut dikuasai oleh pemilik tanah (Suhartono, 1991: 1-2).
}

${ }^{6}$ Nama Pamanoekan en Tjiassemlanden merefleksikan wilayah yang hari ini disebut dengan Kabupaten Subang dengan batas-batas yang sama (Effendhie, 1990: 1).
Dalam perkembangan selanjutnya, saham $P$ en $T$ dijual sebagian kepada Charless Forbes yang berkedudukan di India. Sampai dengan tahun 1839, telah terjadi beberapa kali pergantian pengelola perusahaan $\mathrm{P}$ en $\mathrm{T}$, namun tidak ada satupun yang berhasil mengangkat perusahaan lebih maju lagi. Pada akhirnya, tahun 1842 keseluruhan saham $\mathrm{P}$ en $\mathrm{T}$ dijual kepada tiga orang: John Erich Banck, Peter William Hofland ${ }^{7}$ dan Thomas Hofland ${ }^{8}$ (Broersma, 1912: 14$15)$.

Pada 1848 saham J.E. Banck dibeli oleh Hoffland bersaudara sehingga saham $\mathrm{P}$ en $\mathrm{T}$ saat itu dimiliki oleh keduanya. Namun, P.W. Hofland tidak puas jika saham $\mathrm{P}$ en $\mathrm{T}$ belum dimiliki sepenuhnya atas nama dirinya. Oleh karena itu, pada 1858, saham dari saudara laki-lakinya dibeli olehnya. Sejak saat itu, saham P en $T$ secara resmi dimiliki satu orang saja dan menjadikan P.W. Hofland sebagai penguasa tunggal tanah Subang (Broersma, 1912: 15)

Sekitar 1850, P.W. Hofland memilih Ciherang (Subang) sebagai tempat kediamannya. Selain itu, Ciherang juga dijadikannya sebagai pusat pemerintahan $\mathrm{P}$ en T. Hal ini diperkirakan karena daerah itu terletak di tengah-tengah antara Pamanoekan-Segalaherang yang menjadi ujung utara dan selatan dari tanah $\mathrm{P}$ en $\mathrm{T}$ (Kusma, 2007: 37-38).

Sejak saat itu, perkembangan Ciherang yang hari ini menjadi Kota Subang semakin berkembang ke arah progresif, terutama setelah P.W. menjadi penguasa tunggal. Salah satu perubahan mendasar adalah perubahan jumlah penduduk. Sebelum Ciherang ditetapkan sebagai pusat pemerintahan yaitu pada 1845 , jumlah penduduknya berkisar 8.051

\footnotetext{
${ }^{7}$ Peter William Hofland dilahirkan di Jagernaik Poeram dekat Madras India pada 1802. Lihat Bosma and Raben dalam (Imadudin, 2013: 59).

${ }^{8}$ Thomas Hofland lahir di Jacana Tapoera pada 1799 (Imadudin, 2013: 59).
} 
orang. Setelah menjadi pusat pemerintahan, jumlahnya meningkat tajam pada 1867 yaitu 16.158 orang (Bleeker, 1869: 481).

Pertambahan jumlah penduduk di Subang dibarengi dengan peningkatan kesejahteraan masyarakatnya. Di bawah kepemimpinan P.W. Hofland tanah-tanah yang semula terbengkalai menjadi tanahtanah yang produktif. Hal ini tidak lepas dari kejelian dari tuan tanah saat itu yang melihat bahwa tanah-tanah di Subang memiliki potensi yang cukup besar untuk dikembangkan, terutama untuk perkebunan dan persawahan seperti yang telah dijelaskan terdahulu. Hal ini bukan saja mendatangkan pundi-pundi kekayaan kepada tuan tanah, tetapi juga pekerjaan kepada rakyatnya.

Selain membangun perkebunan ia juga membangun jalan sebagai sarana transportasi yang memudahkan para pekerja menjalankan pekerjaannya. Hal yang lebih penting yang dilakukan oleh P.W. Hofland adalah dibangunnya pasar yang harga-harga barangnya jauh lebih murah dibandingkan dengan toko-toko pedagang Cina. Sementara itu, untuk meningkatkan pengetahuan rakyat Subang, P.W. Hofland membangun sekolah desa dengan pengajaran bahasa Melayu dan aritmatika (Imadudin, 2013: 61).

Pembangunan sarana-sarana di Subang tidak lepas dari meningkatnya jumlah ekspor perusahaan. Ekspor yang paling menguntungkan di antaranya adalah padi, kopi, dan gula (Imadudin, 2013: 64). Artinya, hasil yang didapat dari perusahaan bukan saja untuk kepentingan dirinya, tetapi juga untuk membangun kota dan masyarakatnya. Hal ini mungkin yang mengantarkan Machmoed Effendhie kepada suatu hipotesis bahwa selama P.W. Hofland menjadi tuan tanah, rakyat Subang berada dalam kondisi yang sejahtera sehingga tidak ada pemberontakan. Padahal, di tanah partikelir lainnya seperti di Buitenzorg (Bogor) dan lainnya sering terjadi pemberontakan akibat kesewenangwenangan tuan tanah dalam mengeksploitasi daerahnya. Dengan demikian, dapat dikatakan bahwa pada masa tuan tanah P.W. Hofland berkuasa, rakyat Subang berada dalam kondisi yang baik (Effendhie, 1998: 161) ${ }^{9}$. Kondisikondisi inilah yang membawa Armin Asdi ragu jika sisingaan lahir sebagai gerakan perlawanan. Jika memang waktu yang dipilih untuk menetapkan kelahiran sisingaan adalah sekitar abad ke-19 maka yang terjadi adalah bukan perlawanan melainkan sanjungan kepada Hofland.

Apa yang dilakukan P.W. Hofland nampaknya sulit untuk diikuti oleh para tuan tanah berikutnya. Bahkan Kedua anaknya yaitu Johannes Theodorus dan Egbert Charles selaku pewaris $\mathrm{P}$ en $\mathrm{T}$ tidak mampu untuk mengikuti kepemimpinan ayahnya sepeninggal P.W. Hofland pada 1872.

Setelah diberlakukannya UndangUndang Agraria pada 1870 secara berangsur-angsur pemerintah berupaya untuk mempersempit ruang gerak tuan tanah atas tanahnya dengan dalih melindungi rakyat Indonesia dari kekerasan yang dilakukan tuan tanah. Di sisi lain, di tangan keturunan Hofland, $\mathrm{P}$ en $\mathrm{T}$ tidak berkembang secara signifikan. Pada akhirnya keturunan Hofland menjual tanah itu kepada pemerintah kembali dan kemudian pemerintah menyewakannya kembali dengan hak erfacht ${ }^{10}$ kepada bank Handelsbankpada 1886. Bank tersebut

\footnotetext{
${ }^{9}$ Sejalan dengan Machmoed Effendhie, Armin Asdi dalam Suwardi Alamsyah menjelaskan bahwa kondisi tanah Subang beserta masyarakatnya pada masa kepemimpinan P.W. Hofland berada pada kondisi yang baik. Dikatakan demikian karena Hofland berhasil memajukan perusahaan $\mathrm{P}$ en $\mathrm{T}$ dan memperbaiki kehidupan rakyat Subang (Alamsyah, 2015: 6).

10 Hak erfacht adalah hak benda untuk mendapatkan kenikmatan yang sepenuhpenuhnya dari kepunyaan orang lain dengan kewajiban memberi upeti kepada yang punya tanah baik berupa uang maupun penghasilan lainnya (Tauhid, 2007: 43).
} 
kemudian membentuk N.I Landbouw Maatschapij (Imadudin, 2013: 62-63).

Dalam perkembangan selanjutnya, perusahaan mengalami fluktuatif dan mengarah kepada kemunduran (masa disintegrasi $\mathrm{P}$ en $\mathrm{T}$ ). Setelah dianggap tidak bisa lagi berkembang, pada akhirnya penguasaan tanah Subang kembali lagi ke tangan orang-orang Inggris yaitu kepada suatu perusahaan bernama The AngloDutch Plantation of Java, Limited pada 1910 (Pemerintah Kabupaten Subang tt: 36).

Pada masa ini, perusahaan $\mathrm{P}$ en $\mathrm{T}$ kembali bangkit. Salah satu komoditas unggulannya adalah teh. Namun kebangkitan perusahaan ini dibarengi dengan penekanan yang lebih berat kepada rakyat Subang. Kebijakan menaikkan cukai hingga dua ratus persen membuat rakyat semakin dibebani pekerjaan yang berat. Karena pembayaran cukai dilakukan dengan bekerja kepada perusahaan. Di sisi lain, upah yang diterima tidak mengalami perubahan yang signifikan. Dampaknya, kesejahteraan rakyat mulai terganggu. Sejak saat itu, rakyat Subang mulai aktif melakukan gerakan perlawanan baik dalam skala kecil maupun yang lebih besar (Imadudin, 2013: 165-166).

Pada 1913 terjadi aksi perlawanan yang dilakukan para petani di distrik Pamanukan dan Ciasem. Penyebabnya antara lain meningkatnya cukai yang kemudian berimbas kepada tuntutan kerja yang semakin berat. Pada awalnya, aksi tersebut tidak dapat diredam karena jumlah antara pendemo dan aparat setempat tidak sebanding. Tercatat petani yang melakukan demo sekitar 350 orang. Meskipun demikian, aksi tersebut tidak terkoordinasi dengan baik, hingga pada akhirnya polisi setempat berhasil meredamnya (Imadudin, 2013: 167-176).

Sejak saat itu sampai dengan berakhirnya masa penjajahan Belanda di Indonesia gerakan perlawanan mulai bermunculan di Subang. Hal itu disebabkan karena meningkatnya pajak yang diterima rakyat dan beban kerja yang meningkat. Di sisi lain, hal tersebut tidak lepas dari situasi sosial politik di Subang yang saat itu mulai bermunculan organisasi-organisasi kebangsaan yang pada intinya menuntut kemerdekaan sehingga gelombang perlawanan semakin meningkat.

Dengan demikian, apabila sisingaan dikaitkan dengan gerakan perlawanan seharusnya sisingaan baru lahir setidak-tidaknya setelah 1913. Akan tetapi, kenyataannya tidak demikian, pada 1910 seperti yang telah dipaparkan di awal, sisingaan telah digunakan sebagai upacara syukuran. Oleh karena itu, dapat dikatakan bahwa sisingaan tidak lahir dengan latar belakang perlawanan.

\section{Sisingaan sebagai Bagian dari Islamisasi}

Telah dijelaskan sebelumnya bahwa berdasarkan bukti-bukti yang ada sisingaan tidak lahir dengan latar belakang perlawanan. Akan tetapi, terdapat beberapa hal yang membuat sisingaan dapat diasumsikan sebagai bagian dari proses islamisasi di Subang seperti halnya kesenian gembyung ${ }^{11}$ Subang (wawancara dengan Agustias, 13 Februari 2017). Halhal tersebut yaitu penggunaan singa sebagai wujud kesenian dan fungsi dari sisingaan itu sendiri.

Penggunaan singa sebagai wujud kesenian Sisingaan menjadi menarik untuk dikaji lebih dalam lagi. Sebab, masyarakat Sunda tidak mengenal binatang itu. Dengan demikian, muncul dugaan telah masuknya pengaruh asing ke Subang.

Rute perdagangan dan pelayaran antara Kepulauan Indonesia dengan negerinegeri di Timur Tengah seperti Persia telah dikenal sejak zaman dahulu (Algadri,

\footnotetext{
${ }^{11}$ Menurut cerita masyarakat, kesenian gembyung lahir untuk menarik minat anak kecil agar mau dikhitan karena masyarakat saat itu merasa takut ketika akan dikhitan (wawancara dengan Agustias, 13 Februari 2017).
} 
1988: 45). Temuan arkeologis berupa manik-manik yang ditemukan di kawasan situs Subanglarang menunjukkan adanya hubungan antara masyarakat Kepulauan Indonesia, khususnya Subang, dengan orang-orang yang berasal dari Asia Selatan ${ }^{12}$.

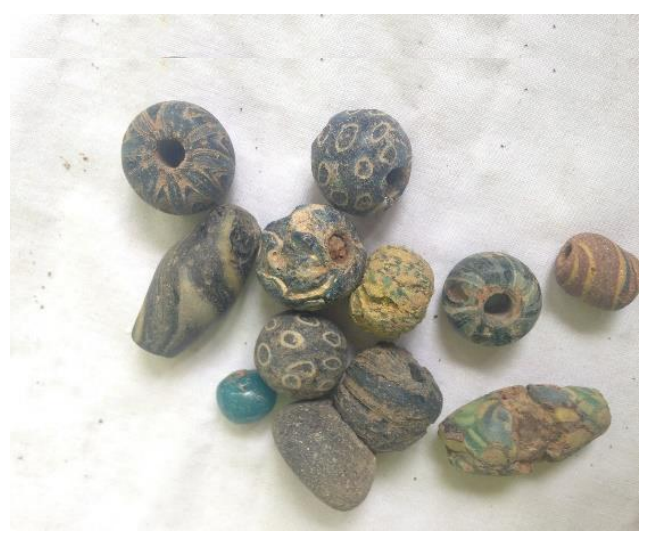

Gambar 3. Manik-manik di Subang Sumber: Hasil foto penulis pada 13 Februari 2017

Di kawasan Asia Selatan telah berdiri Kerajaan Islam pada abad ke-15 yang dikenal dengan nama Kerajaan Mughal ${ }^{13}$ dengan Delhi sebagai ibu kotanya. Kerajaan ini memiliki bendera berwarna hijau yang terdapat gambar matahari dan singa seperti yang terdapat pada bendera Kerajaan Safawi (Persia).

\footnotetext{
${ }^{12}$ Manik-manik yang ditemukan di Subang berasal dari kawasan Asia Selatan. Hal ini didasarkan pada bentuk ukiran yang terdapat pada manik-manik tersebut. Selain itu, ukiran tersebut menunjukkan waktu yang diperkirakan sekitar abad ke-15. Lihat dalam lampiran Dubin, Lois Sherr. The History of Beads From 30.000 B.C. to the Present (London: Thames and Hudson Ltd, 1995) hlm. 136.

${ }^{13}$ Kerajaan Mughal didirikan oleh Zahirudin Babur. Kerajaan ini adalah salah satu dari tiga Kerajaan Islam besar pada masa itu. Lihat Yatim, Badri. Sejarah Peradaban Islam (Jakarta: PT Raja Grafindo Persada, 2008: 147).
}

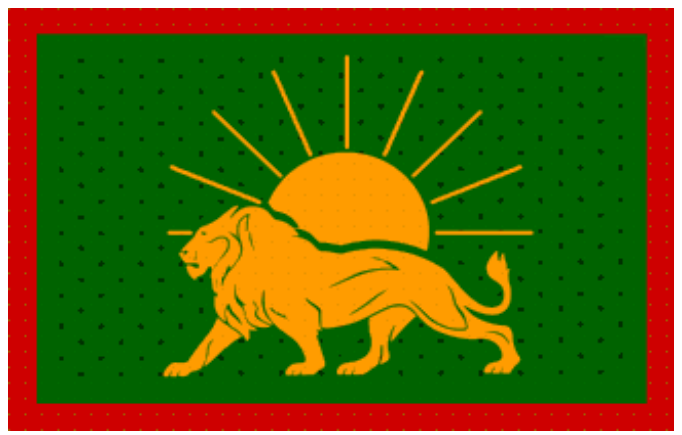

Gambar 4. Bendera Kerajaan Mughal Sumber: https://www.quora.com/What-did-theMughal-Empires-flag-symbolize.

Bendera sebagai salah satu wujud identitas suatu bangsa (dalam hal ini kerajaan) biasanya digunakan sebagai simbol dan identitas pembawanya (Burke, 2015: 83). Karena identitas merupakan proses yang penting dalam berkomunikasi baik antarindividu maupun antarkelompok (Littlejohn \& Foss, 2009: 139). Sebagai contoh, ekspansi yang dilakukan oleh sebuah kerajaan umumnya menyertakan bendera kerajaannya. Setelah mereka berhasil menguasai wilayah baru tersebut pasti akan menandainya dengan mengibarkan bendera yang dibawa itu. Dalam dunia perdagangan dan pelayaran (termasuk di dalamnya penyebaran agama Islam) bendera biasanya diletakkan di tiang kapal (bagian atas) ${ }^{14}$ yang secara tidak langsung merupakan penyebarluasan simbol dan identitas. Maka, diperkirakan pengetahuan penduduk Subang pada singa terjadi ketika orang-orang dari India melakukan proses komunikasi dengan masyarakat setempat terutama orang-orang yang hidup dan tinggal di lokasi manikmanik tersebut ditemukan. Adapun proses komunikasi tersebut berkaitan erat dengan proses penyebaran agama Islam karena sejak abad ke-7 hingga abad ke-15 orangorang yang berasal dari Arab, Persia dan India sedang gencar-gencarnya

\footnotetext{
${ }^{14}$ Lihat dalam Chaudhuri, K.N. Trade and Civilization in the Indian Ocean: An Economic History from the Rise of Islam to 1750 (United Kingdom: Cambridge University Press, 2002) hlm. 149 \& 154.
} 
menyebarkan agama Islam di Indonesia (Ali \& Effendy, 1986: 29-30).

Sampai saat ini proses islamisasi di Subang diyakini dilakukan oleh seorang pemuda dari Talaga bernama Aria Wangsa Goparana (Kusma, 2007: 20). Namun, menurut cerita yang berkembang di masyarakat terdapat tokoh lainnya yang telah menyebarkan agama Islam di Subang yaitu Subanglarang beserta para santrinya. Dikatakan bahwa ia membangun pesantren di Amparan Alif (sekarang kawasan Situs Subanglarang). Setelah membangun pesantren di sana, Subanglarang kemudian berkelana ke seluruh Subang untuk menyebarkan agama Islam. Begitupun dengan santri-santri pesantren yang ditinggalkannya. Santri-santri yang telah dididik Subanglarang juga aktif menyebarkan agama Islam di lingkungan pesantren. Tidak hanya itu, mereka juga aktif mnyebarkan agama Islam ke seluruh Subang serta daerah-daerah lainnya di luar Subang (wawancara dengan Abah Dasep, 9 Februari 2017).

Upaya mengislamkan masyarakat Subang oleh mereka nampaknya dilakukan dengan berbagai cara seperti yang dilakukan orang-orang pada masanya melalui berdagang, pernikahan, guru agama ( $\left.d a^{\prime} i\right)$, dan kesenian. Khusus yang terakhir disebutkan, cara itu melekat pada penyebar Islam di Jawa yang dikenal dengan sebutan Walisongo. Cara-cara itu dapat ditemui pada kesenian wayang yang ceritanya bernuansakan Islam (Tajuddin, 2014: 385). Cara tersebut nampaknya diikuti para santri untuk menyebarkan agama Islam di Subang dengan wujud kesenian sisingaan.

Telah dijelaskan di awal bahwa Sisingaan pada awalnya difungsikan untuk mengarak anak-anak saat akan dikhitan. Nampaknya, kesenian sisingaan dalam kaitannya dengan proses islamisasi di Subang digunakan untuk menegakkan syariat Islam yang terwujud dalam proses khitanan.

Jadi, sisingaan dan Islam memiliki kaitan yang cukup erat sehingga tidak berlebihan kiranya untuk mengatakan bahwa sisingaan merupakan bagian integral dari islamisasi di Subang.

\section{Sisingaan sebagai Upaya Penghormatan kepada P.W. Hofland}

Selain diasumsikan sebagai upaya islamisasi di Subang, kesenian sisingaan pun dapat diasumsikan sebagai upaya penghormatan kepada seseorang yang telah banyak berjasa kepada Subang yaitu Peter Willem Hofland.

P.W. Hofland adalah orang yang banyak memberikan kontribusi bagi perkembangan Subang. Tercatat ada beberapa hal yang dapat dikemukakan mengenai jasa-jasanya; pertama, ia adalah orang yang menjadikan tanah Subang yang semula tidak produktif menjadi lebih produktif pada masanya (Asdi, dkk., 1980: 40-41). Kedua, pembangunan kota termasuk saluran irigasi telah menambah jumlah produksi berbagai tanaman komoditas ekspor meningkat yang pada akhirnya berpengaruh terhadap peningkatan kesejahteraan rakyat Subang. Meningkatnya jumlah penduduk secara signifikan di Subang sejak ia menjadi tuan tanah merupakan bukti telah meningkatnya kesejahteraan penduduk di sana sebagamana dipaparkan di awal.

Prestasi-prestasi yang telah ditorehkan oleh P.W. Hofland tersebut membuat namanya semakin dikenal oleh dua kalangan. Pertama Pemerintah HindiaBelanda dan kedua oleh rakyat Subang sendiri.

Kerja sama yang dilakukan P.W. Hofland dengan pemerintah terkait dengan komoditas ekspor menjadi penyebab dirinya dikenal baik oleh pemerintah karena melalui dirinya pemerintah mendapatkan keuntungan dari sisi ekonomi. Sehingga setelah ia meninggal pada 1872, ia dianugerahi penghargaan oleh Kerajaan Belanda dengan julukan The Order of Netherlands Lion. Selain itu dibangun pula makam untuknya yang cukup megah dan mencolok dibanding 
dengan makam lainnya (Daukes, 1943: 2223).

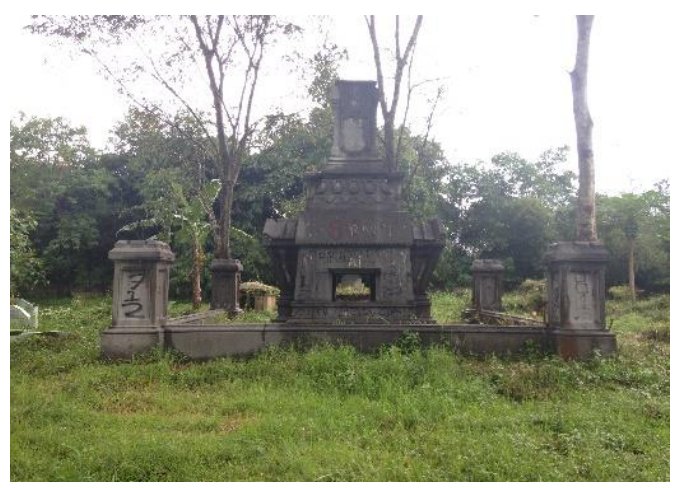

Gambar 5. Makam P.W. Hofland di Subang Sumber: Anggi Agustian J. pada 4 Maret 2017.

Di sisi lain, masyarakat Subang mengenal baik P. W. Hofland. Perkembangan kota selalu diikuti dengan perkembangan masyarakat yang dalam hal ini berarti peningkatan kesejahteraannya (Rahardjo, 1983: 11). Sebagaimana telah dijelaskan terdahulu bahwa P. W. Hofland telah berhasil mengembangkan kota dan masyarakatnya melalui irigasi dan pemanfaatan tanah. Dampaknya, masyarakat berada dalam kondisi yang cukup baik. Hal ini dibuktikan dengan tidak terdapatnya perlawanan dari rakyat Subang selama ia berkuasa. Lebih jauh, bukti yang dapat dikemukakan lagi antara lain patung $\mathrm{P}$. W. Hofland yang terdapat di tempat peristirahatannya. Biasanya, ketika masa revolusi fisik berlangsung, bangunan-bangunan yang menjadi simbol orang Belanda atau penjajah akan dirusak untuk menghilangkan nuansa penjajahan di daerah tersebut. Seperti yang terjadi pada bangunan pemerintah jajahan di Subang seperti Kantor Besar P en T, Atelier, Gedong Hejo, Gedung Tuan Houwing dan yang lainnya yang dibumihanguskan. Namun demikian, patung P. W. Hofland tidak ada yang merusaknya. Bahkan sampai kini patung tersebut dapat dilihat di Museum Wisma Karya Subang secara utuh tanpa adanya kerusakan sedikitpun.

Hal itu menunjukkan kepada kita untuk sampai kepada pemikiran bahwa apa yang dikemukakan Machmoed Effendhie dalam tesisnya, kemudian Armin Asdi dengan asumsinya seperti yang telah dijelaskan di awal dapat diterima.

Berdasarkan kenyataan-kenyataan di atas kiranya dapat dimungkinkan bahwa kesenian sisingaan dibuat untuk menghormati P. W. Hofland mengingat gelar yang didapatnya dari Kerajaan Belanda adalah Lion atau singa. SelPin itu, jika benar sisingaan lahir pada masa ia berkuasa maka dapat dipastikan hal tersebut bukan sebagai perlawanan karena kondisi masyarakat berada pada tingkat kesejahteraan yang cukup baik.

Namun siapakah yang menjadi pencetusnya? Tentu saja bukan dari kalangan bawah dalam strata sosial masyarakat Subang. Ia adalah para elite ${ }^{15}$ yang secara sosial memiliki kedekatan dengan tuan tanah karena mereka penyambung lidah di antara penguasa dan yang dikuasai.

Adapun kaitan antara sisingaan dengan gerakan perlawanan rakyat Subang merupakan simbol yang muncul belakangan terutama pasca seminar kesenian sisingaan yang diselenggarakan pada 1988 (Mulyadi, 2003:5). Artinya telah terjadi perubahan simbol pada sisingaan.

Munculnya simbol sisingaan sebagai bentuk perlawanan dapat kita pahami melalui kultuurgebundenheit (ikatan kebudayaan) dan zeitgeist (jiwa zaman). Pada 1913 rakyat Subang mulai melakukan gerakan perlawanan terhadap tuan tanah. Kemudian pada periode 19451949 rakyat Subang berada pada periode

\footnotetext{
${ }^{15}$ Yang dimaksud dengan golongan elite disini ialah mereka yang disebut oleh Geertz sebagai golongan priyayi. Van Niel kemudian menambahkan bahwa para priyayi bekerja sebagai pejabat-pejabat administrasi pemerintahan pribumi dan oleh sebab itu mereka dipersilahkan oleh pemerintah kolonial untuk menggunakan gelar Raden atau Raden Mas. Lihat Kartodirdjo, Sartono, Perkembangan Peradaban Priyayi, (Yogyakarta: Gadjahmada University Press, 1987) hlm. 1-5.
} 
mempertahankan kemerdekaan. Dan terakhir periode 1949-1968 merupakan periode peralihan. Disebut peralihan karena meskipun Indonesia telah merdeka, tanah Subang secara administrasi masih menjadi milik perusahaan asing, sehingga belum merdeka sepenuhnya. Baru setelah 1968, Subang mendapatkan kemerdekaannya secara penuh. Dengan demikian dapat dikatakan bahwa periode 1913-1968 merupakan periode perjuangan rakyat Subang melawan tuan tanah atau penjajah. Oleh karenanya, wajar bila simbol perjuangan pada Sisingaan muncul di benak orang-orang saat itu karena sesuai dengan jiwa zamannya.

\section{PENUTUP}

Berdasarkan uraian di atas dapat disimpulkan bahwa kesenian sisingaan merupakan kesenian yang berasal dari daerah utara Provinsi Jawa Barat bernama Kabupaten Subang. Pendapat yang mengatakan bahwa kesenian sisingaan lahir dengan latar belakang perlawanan tidak dapat lagi diterima karena terdapat bukti-bukti yang membantah hal itu. Adapun latar belakang lahirnya sisingaan yang didasarkan pada uraian di atas setidak-tidaknya menghasilkan dua indikasi. Pertama, kesenian sisingaan lahir sebagai bagian dari proses islamisasi di Subang yaitu untuk menegakkan syariat Islam di daerah tersebut. Hal itu tercermin pada fungsi awal sisingaan yaitu untuk mengarak anak-anak yang akan dikhitan.

Kedua, indikasi berikutnya
mengarah penghormatan, atau penghargaan kepada $\mathrm{P}$. W. Hofland. Ia merupakan orang yang banyak berjasa terhadap perkembangan Subang beserta penduduknya. Terdapat kesan kuat bahwa ia tidak hanya mementingkan keuntungan semata selama ia menjadi tuan tanah di Subang sehingga tidak heran apabila penduduk Subang baik elit pribumi maupun rakyat biasa membuat suatu karya seni untuk menghormatinya dalam wujud kesenian sisingaan sebagaimana gelar yang didapatnya dari pemerintah.

Namun demikian, asumsi-asumsi yang telah dijelaskan oleh penulis di atas jangan sampai menimbulkan suatu penerimaan pandangan tanpa pertanyaan. Artinya, asumsi-asumsi tersebut harus didukung oleh fakta-fakta yang lebih akurat lagi. Sampai saat penulis menuliskan tulisan ini belum dapat ditemukan bukti yang sangat akurat, terutama indikasi yang kedua. Oleh karenanya, penulisan lanjutan dengan penelitian yang lebih mendalam dan kritis memungkinkan untuk dilakukan. Bahkan, dalam penelitian itu dapat mendukung ataupun membantah argumen-argumen yang terdapat dalam tulisan ini. Paling tidak, tulisan ini menjadi landasan awal untuk sampai kepada pemikiran yang baru mengenai sisingaan dalam tinjauan historisnya.

\section{UCAPAN TERIMA KASIH}

Karya yang sederhana ini tidak akan dapat tercapai tanpa izin Allah Swt. Selain itu, penulis menyadari bahwa tanpa bantuan dari berbagai pihak tidak mungkin tulisan ini dapat selesai. Penulis mengucapkan banyak terima kasih kepada Tolib Rohmatillah M. A. karena telah memberikan arahan dan bimbingannya dalam menyelesaikan tulisan ini. Kemudian kepada Etty Saringendyanti M. Hum. dan Budimansyah Suwardi, S. Ars, penulis juga haturkan terima kasih karena telah meluangkan waktu untuk berdiskusi terkait dengan tulisan ini. Dari hasil diskusi tersebut penulis mendapatkan ide yang secara langsung telah membuka wawasan penulis sehingga dapat menghadirkan tulisan ini. Selain itu, penulis juga menghaturkan terima kasih kepada para penulis atau peneliti sisingaan terdahulu seperti Edih, Mulyadi dan Nanu Munajar. Melalui tulisan-tulisan mereka lah penulis tergerak untuk melengkapinya melalui tulisan ini. Serta penulis haturkan terima kasih kepada para reviewer Jurnal Patanjala karena telah mengkritisi tulisan 
ini sehingga didapatkan tulisan yang lebih baik lagi.

\section{DAFTAR SUMBER}

\section{Jurnal IImiah, Tesis, Disertasi}

Alamsyah, Suwardi. "Sisingaan; Kesenian Kabupaten Subang", Makalah dalam Kegiatan BPNB, Bandung: BPNB, 2015.

Dewi, Jilly N, Sumarno, Sumarjono. "Perkembangan Kesenian Sisingaan di Kabupaten Subang Tahun 1955-2013" dalam artikel ilmiah mahasiswa 1 (1): 1-12, 2015.

Effendhie, Machmoed. 1990. Dari Tanah Partikelir $P$ en $T$ Menuju Tanah Merdeka: Draft Pendahuluan Monografi (Kab) Subang 1900-1968. Bogor: Lembaga Penelitian Institut Pertanian Bogor.

Effendhie, Machmoed. 1998.

Negara Kecil dalam Negara: Kondisi Sosial-Ekonomi di tanah Partikelir Pamanoekan dan Ciasem 1813-1910. Tesis. Yogyakarta: Program Pasca Sarjana UGM.

Imadudin, Iim. 2013.

Kehidupan Sosial-Ekonomi Buruh di Tanah Partikelir Pamanukan dan Ciasem (1910-1969). Tesis. Bandung: Program Pasca Sarjana Ilmu Sejarah Unpad.

Mulyadi, T. "Sisingaan Kemasan Wisata di Kabupaten Subang" dalam Anonim. Vol. 2 No. 2. 2003.

Rachmawaty, Enden I. "Nilai Estetika dalam Sisingaan di Kabupaten Subang" dalam Jurnal Ilmiah Patanjala Vol.5 No.3. 2013.

Saini, K.M. "Political Theatre: Indonesian Case" dalam Jurnal Ilmiah Seni dan Budaya Panggung Nomor XX. September 2002. Bandung: Puslitmas STSI Bandung.

Tajuddin, Yuliyatun. "Walisongo dalam Strategi Komunikasi Dakwah" dalam Jurnal Ilmiah Addin. Vol.8 No. 2. 2014.

\section{Buku-Buku}

Algadri, Hamid. 1988.

Islam dan Keturunan Arab dalam Pemberontakan Melawan Belanda. Bandung: Mizan.

Ali, Fachry \&Effendy, Bahtiar. 1986. Merambah Jalan Baru Islam: Rekonstruksi Pemikiran Islam Indonesia Masa Orde Baru. Bandung: Mizan.

Asdi, et all. 1980.

Hari Jadi Kabupaten Subang dengan Latar Belakang Sejarahnya. Subang: Pemerintah Kabupaten Subang.

Bleeker, P. 1869.

Nieuwe Bijdragen Tot de Kennis der Bevolking Statistiek van Java. Netherlands: KITLV.

Broersma. 1910.

De Pamanoekan en Tjiassem-Landen. Batavia: Drukkerij Papyrus.

Burke, Peter. 2015.

History and Social Theory, second edition. Diterjemahkan oleh Mestika Zeid, Zulf Almi, dan A. Sairozi. Sejarah dan Teori Sosial, edisi kedua. Jakarta: Yayasan Pustaka Obor Indonesia.

Chaudhuri, K.N. 2002.

Trade and Civilization in the Indian Ocean: An Economic History from the Rise of Islam to 1750. United Kingdom: Cambridge University Press.

Daukes, W.H. 1943. The P \& T Lands: An Agricultural of Anglo-Dutch Enterprise. Amsterdam: P\&T.

Dubin, Lois Sherr. 1995.

The History of Beads From 30.000 B.C. to the Present. London: Thames and Hudson Ltd.

Gottschalk, Louis. 2008. Understanding History. Diterjemahkan oleh Nugroho Notosusanto. Mengerti Sejarah. Jakarta: UI-Press.

Herlina, Nina. 2008.

Metode Sejarah. Bandung: Satya Historika. 
Kartodirdjo, Sartono. 1987. Perkembangan Peradaban Priyayi. Yogyakarta: Gadjah Mada University Press.

Kuntowijoyo. 2013.

Pengantar Ilmu Sejarah. Yogyakarya: Tiara Wacana.

Kusma, dkk. 2007.

Sejarah Kabupaten Subang. Subang: Pemerintah Kabupaten Subang.

Littlejohn, Stephen, W \& Foss, Karen, A. 2009.

Encyclopedia of Communication Theory. California: SAGE Publications, Inc.

Rahardjo. 1983.

Perkembangan Kota dan Permasalahannya. Jakarta: PT Bina Aksara.

Soekardi, Yuliadi. 2006.

Asal Mula Kesenian Sisingaan. Bandung: CV Pustaka Setia.

Suhartono. 1991.

Apanage dan Bekel: Perubahan Sosial di Pedesaan Surakarta 1830-1920. Yogyakarta: PT Tiara Wacana Yogya.

Tauhid, Mochammad. 2011.

Masalah Agraria: sebagai Masalah Penghidupan dan Kemakmuran Rakyat Indonesia. Jakarta: Yayasan Bina Desa.

Yatim, Badri. 2008.

Sejarah Peradaban Islam: Dirasah islamyah II. Jakarta: PT Raja Grafindo Persada.

\section{Informan}

a. Nama

Umur

Pekerjaan

: Abah Dasep

: 70 tahun

: Budayawan

b. Nama

:Muhammad

Umur

Agustias Amin

Pekerjaan

: Kepala Humas

Kabupaten Subang

\section{Internet}

https://www.quora.com/What-did-the-MughalEmpires-flag-symbolize. Diakses pada tanggal 13 Maret 2017 pukul 12.30 WIB.

http://symbolsnet.com/symbols/netherlansnational-symbol.html. Diakses pada 9 Mei 2017 pukul 11.46 WIB.

http://ispu.ru/files/The_UK.pdf. Diakses pada 9 Mei 2017 pukul 11.46 WIB. 